\title{
PENGAMBILAN KEPUTUSAN DALAM MERAWAT PASIEN GANGGUAN JIWA TANPA MENGGUNAKAN PASUNG
}

\author{
Nadilla Juliansyah Harun/ nadillavivo7@gmail.com
}

\section{Latar belakang}

Kesehatan jiwa adalah suatu kondisi seseorang yang dapat memungkinkan dia memiliki kehidupan yang sejahtera dan harmonis,mampu berbaur dengan lingkungan,mampu mengendalikan emosi,stress, mampu mengenali diri sendiri dengan baik dan nyaman bersama orang lain. Gangguan jiwa adalah gangguan mental seseorang dalam berfikir,tindakan,emosi,kemauan. Gangguan jiwa adalah keadaan fisik dan mental yang tidak normal. Dalam gangguan jiwa ini banyak orang yang kehilangan kesadaran diri,seperti tidak mengenal diri sendiri,lebih suka terbawa perasaan seperti mudah menangis,mudah marah. Manusia bereaksi secara holistic (keseluruhan) yang melibatkan unsur organobioliologis,psychoeducative, sosiocultural. Ketiga unsur ini sangat diperhatikan ketika dalam mencari penyebab gangguan jiwa.

Pemasungan di Indonesia merupakan salah satu permasalahan dibidang kesehatan jiwa di Indonesia yang menunjukkan pasien gangguan jiwa belum sepenuhnya bisa mendapatkan perlakuan yang baik serta memenuhi hak asasi manusia. Banyak dampak yang disebabkan oleh pemasungan seperti merasa depresi,adanya niatan bunuh diri,trauma,merasa dibuang atau terasingkan dari keluarga. Tindakan keluarga dengan melakukan pemasangan pasung dikarenakan kurangnya pengetahuan keluarga dalam mengenali penyakit. Keluarga merasa malu dengan lingkungan sekitar karena memiliki anggota keluarga yang mengalami gangguan kejiwaan atau tidak adanya biaya keluarga untuk pengobatan pasien,padahal Keluarga adalah peran yang paling utama dalam proses penyembuhan pasien. Adanya dukungan dari keluarga adalah sebuah motivasi yang sangat diperlukan oleh penderita gangguan jiwa dalam proses pengobatan dan perawatan.Upaya yang dapat dilakukan untuk bisa mencegah keluarga mengambil keputusan melakukan pemasungan terhadap pasien gangguan jiwa yaitu dengan terapi keluarga yang dikenal dengan terapi keputusan perawatan tanpa pasung (KPTP).

Metode: Metode yang digunakan dalam kajian ini adalah metode Literature review dengan menganalisis dan mengeksplorasi dari referensi yang berbeda,juga dilengkapi dengan ejournal yang mendukung dengan judul kajian ini.

Hasil: Menunjukkan bahwa pemasangan pasung bisa menyebabkan pasien gangguan jiwa mengalam trauma,depresi dan merasa terasingkan. Upaya yang dapat dilakukan untuk mencegah keluarga membuat keputusan untuk melakukan pemasungan yaitu dengan memberi edukasi dan memandu keluarga dalam pengambilan keputusan perawatan tanpa pasung pada pasien gangguan jiwa khususnya yang berprilaku agresif. 


\section{PEMBAHASAN}

Kesehatan jiwa adalah suatu kondisi kesehatan mental,fisik,sosial yang sejahtera. Apabila kondisi fisik kita sehat maka mental kita juga sehat namun begitu pula sebaliknya jika kondisi mental kita sakit maka fisik kita akan tergangu. Gangguan jiwa adalah gangguan dalam berpikir, kemauan,emosi dan tindakan. Salah satu negara tertinggi di dunia yang memiliki angka kejadian gangguan jiwa yang tinggi adalah Indonesia. Contoh gangguan jiwa seperti skizofrenia depresi retardasi mental dan juga gangguan akibat penyalahgunaan narkoba sebagai isu yang perlu mendapatkan perhatian dunia (WHO 2012). Skizofrenia adalah gangguan jiwa yang ditandai dengan ketidakmampuan atau penurunan komunikasi gangguan realita atau halusinasi pasien skizofrenia dapat mengalami kesulitan dalam berpikir yang benar memahami dan juga menerima realita gangguan dalam Emosi tidak dapat membuat keputusan dan gangguan dalam beraktivitas.

Kendala dalam layanan kesehatan jiwa adalah keterbatasan ketersediaan obat-obatan bagi pasien dengan gangguan jiwa. Seandainya tersedia, harga obat belum terjangkau oleh sebagian masyarakat,karena pada umumnya orang dengan gangguan jiwa memerlukan pengobatan dalam waktu yang lama. Pada beberapa kasus, obat-obatan jiwa tidak pernah digunakan

Tugas keluarga adalah kegiatan yang dilakukan Caregiver di rumah yang dapat membantu proses penyembuhan pasien. Fungsi pemeliharaan kesehatan, keluarga mempunya peran di bidang kesehatan meliputi (Friedman,2010)

Family caregiver adalah individu yang secara umum merawat dan mendukung anggota keluarga yang sakit dalam menjalani kehidupannya (Awad \& Voruganti 2008).Awad dan Voruganti (2010) menambahkan bahwa family caregiver adalah individu yang memberikan bantuan informal dan tidak dibayar kepada anggota keluarga yang membutuhkan bantuan fisik dan emosional.Penelitian Fadli (2013) mengatakan semakin baik sikap dan tingginya dukungan family caregiver semakin berkurang frekuensi kekambuhan klien dan terdapat hubungan semakin meningkat ekspresi emosi family caregiver semakin meningkatkan frekuensi kekambuhan klien ditentukan dengan dukungan family caregiver.

Menurut penelitian Claudia (2016) bahwa perempuan cenderung mempunyai perilaku yang tinggi untuk mengikuti aktifitas dan kegiatan, karena perempuan lebih tekun dan senang berkumpul dengan teman seusianya. Adanya keluarga dengan gangguan jiwa dirumah akan menghambat aktifitas dan kegiatan sosial yang dilakukan sehingga muncul intensi pasung pada keluarga yang mengalami gangguan jiwa. Alasan keluarga mengambil keputusan untuk melakukan pemasangan Pasung yaitu kondisi sosial ekonomi,untuk mencegah pasien dalam melakukan tindakan kekerasan terhadap dirinya maupun orang lain, agar pasien gangguan jiwa tidak kabur dari rumah, faktor kemiskinan dan juga kurangnya pendidikan dan pengetahuan keluarga terhadap dampak dalam pemasangan pasung. 


\section{Langkah pengambilan keputusan dalam berpikir kritis Untuk mencegah pemasangan pasung pada pasien gangguan jiwa}

1. Memberikan asuhan keperawatan jiwa kepada pasien merupakan suatu kompetensi yang dilakukan perawat terdiri dari tahapan askep dan juga format dokumentasi askep. Tahapan dalam pemberian asuhan keperawatan yaitu meliputi pengkajian, perencanaan, implementasi dan evaluasi.

2. Peran perawat sebagai pelaksana. Dalam mencegah ide bunuh diri pada pasien gangguan jiwa adalah dengan memberikan perhatian dan rasa kasih sayang dan penghargaan sosial kepada pasien, mengawasi kepatuhan pasien dalam minum obat,membantu pasien untuk selalu berinteraksi dengan lingkungan,memberi kegiatan yang positif untuk mengisi waktu pasien, jangan biarkan pasien menyendiri, memberikan pujian jika pasien melakukan hal yang positif, jangan mengkritik pasien jika pasien melakukan suatu kesalahan, menjauhkan pasien dari keadaan yang bisa membuat penderita merasa tidak berdaya dan tidak berarti (Shives,1998). Beberapa factor yang menjadi perhatian bagi perawat dalam kasus pencegahan bunuh diri adalah riwayat adanya kekerasan, adanya proses psikotik yang mempengaruhi kekerasan atau hilangnya control impuls akut, hasil anamnesa yang tepat tentang makna rencana dan juga tujuan pasien yang melakukan bunuh diri ( Shawn 1996 ).

3. Melanjutkan terapi untuk penderita. perawat membantu terapi dan pengobatan lanjutan bagi pasien gangguan jiwa. Terapi yang harus perawat berikan kepada pasien yaitu berdasarkan rujukan balik dari RSJ dan juga menganjurkan keluarga untuk membawa pasien ke puskesmas untuk bisa mendapatkan injeksi obat jiwa dalam sekali sebulan.

4. Perawat kesehatan jiwa juga memberikan pendidikan kesehatan jiwa kepada keluarga pasien seperti menyarankan keluarga agar memperlakukan pasien dengan baik, mengarahkan keluarga untuk memenuhi kebutuhan dasar penderita, misalnya makan, mandi,mengajak pasien untuk berkomunikasi, mengajak pasien untuk bersosialisasi ke lingkungan sekitar pasien, atau memberikan kesibukan pada pasien.

5. Setiap individu didalam keluarga harus saling terhubung dan berinteraksi sebagai kelompok, oleh karena itu segala sesuatu yang terjadi pada salah satu dari mereka akan berpengaruh terhadap yang lainnya, seperti ketika salah seorang dalam keluarga menderita gangguan jiwa maka akan berpengaruh terhadap yang lainnya. Hal ini menunjukan bahwa sangat penting adanya peran dan pemahaman keluarga mengenai kesalahan tindakan pemasungan dan pemberian motivasi kepada keluarga.

6. Memberikan edukasi tentang pendidikan kesehatan pencegahan pemasangan pasung pada keluarga, pendidikan kesehatan efektif terhadap peningkatan intensi keluarga untuk mencegah tindakan pemasungan pada orang dengan gangguan jiwa. 
7. Upaya untuk mencegah keluarga mengambil keputusan dalam melakukan pemasungan terhadap pasien skizofrenia, maka diperlukan suatu terapi yang bisa mengedukasi dan memandu keluarga dalam pengambilan keputusan perawatan tanpa pasung pada pasien skizofrenia khususnya perilaku pasien yang agresif (Keliat, 2015). Terapi yang dibutuhkan untuk membantu menyelesaikan masalah pasien gangguan jiwa adalah terapi modalitas keperawatan jiwa. Terapi modalitas keperawatan jiwa yang terdiri atas terapi individu, keluarga, kelompok, lingkungan.

Pemberian terapi KPTP bertujuan memandu keluarga mengambil keputusan secara sistematis dan logis dengan mempertimbangkan berbagai konsekuensi dari setiap alternative pilihan tindakan yang tersedia melalui keputusan perawatan yang tepat dan terapeutik dengan urutan langkah-langkah logis penyelesaian masalah yang disusun secara sistematis dimulai dengan mengidentifikasi stressor akibat memiliki anggota keluarga yang mengalami gangguanjiwa di rumah,dilanjutkan dengan mengidentifikasi stress atau respons terhadap stressor tersebut,kemudian mengidentifikasi konsekuensi dari empat pilihan perawatan yang tersedia untuk menyelesaikan stress akibat memiliki anggota keluarga yang mengalami gangguan jiwa. Langkah berikutnya adalah memilih keputusan yang akan diambil dan akhirnya memutuskan pilihan tersebut sebagai alternative penyelesaian masalah stress dalam keluarga.

Terapi KPTP menyebabkan terjadinya penurunan keinginan keluarga melakukan pemasungan pada pasien skizofrenia,menurut Stuat (2016) salah satu terapi yang dibutuhkan untuk membantu menyelesaikan masalah pasien gangguan jiwa adalah terapi keperawatan, khususnya terapi modalitas keperawatan jiwa. Terapi modalitas keperawatan jiwa terdiri atas terapi individu,keluarga, kelompok, lingkungan, somatik yang dalam implementasi di Indonesia difokuskan pada tiga kelompok terapi yaitu terapi individu, kelompok dan keluarga.Terapi keluarga yang dikembangkan oleh Daulima (2014), bertujuan membantu pencegahan tindakan pasung oleh keluarga kepada pasien gangguan jiwa yang dikenal dengan terapi keputusan perawatan tanpa pasung (KPTP). Perawat berperan dalam memberikan penyuluhan kepada masyarakat. Pemberdayaan untuk meningkatkan pengetahuan masyarakat tentang gangguan jiwa dan gangguan emosional pada level- level tertentu perlu dilakukan agar tidak menimbulkan stigma terhadap penderita gangguan jiwa yang bisa disembuhkan . Promosi kesehatan dengan role play dan ceramah dapat meningkatkan pengetahuan keluarga dan tokoh masyarakat.

\section{Penutup}

Pencegahan pemasangan pasung pada pasien gangguan jiwa harus diterapkan pada keluarga yang memiliki anggota keluarga pasien gangguan jiwa. Keluarga dan masyarakat harus diberi edukasi tentang pendidikan kesehatan tentang pemasangan pasung,dan dampak dari pemasangan pasung pada pasien gangguan jiwa. Perawat sebagai pelaksana memberikan asuhan keperawatan yang baik agar pasien tidak melakukan hal yang diluar dugaan seperti pasien memiliki ide untuk bunuh diri,memberikan rasa kasih sayang kepada pasien. 


\section{Daftar pustaka}

1. Arfiandinata,N. Sumartyawati,N.M. (2013). Hubungan Kemampuan Keluarga Dalam Memutuskan Tindakan yng Tepat dengan Peran Informal Keluarga pada Anggota Keluarga yang Mengalami Gangguan Jiwa di Desa Pijot Wilayah Kerja Puskesmas Keruak. Prosiding Konferensi Nasional PPNI Jawa Tengah.

2. Darwan,S.Buanasari, A.Kundre,R. (2019). Pengaruh Pendidikan Kesehatan Pencegahan Pasung Terhadap Intensi Pasung Pada Keluarga ODGJ di Rumah Sakit Jiwa Prof. Dr.V.Ratumbuysang Manado. e-journal Keperawatan (eKp). Vol 7

3. Jayanti,D.M.A.D.Mirayanti,N.K.A.Arwidana,D.P. (2020) . Pengaruh Terapi Keputusan Perawatan Tanpa Pasung (KPTP) Terhadap Penurunan Keinginan Melakukan Pemasungan. Jurnal SMART Keperawatan . Vol 7

4. Niman,S. (2019). Pengalaman Family Caregiver dalam Merawat Anggota Keluarga yang Mengalami Gangguan Jiwa. Jurnal Keperawatan Jiwa. Vol 7

5. Nyumirah,S. (2014). Manajemen Asuhan Keperawatan Spesialis Jiwa Pada Klien Halusinasi di Ruang Sadewa di RS Dr. H. Marzoeki Mahdi Bogor. Jurnal Keperawatan Jiwa. Vol 2

6. Pujianto,T. Agustin,R.A. (2017). Peran Keluarga dalam Perawatan Pasien Gangguan Jiwa. Jurnal Ners dan Kebidanan. Vol 4

7. Rahman,A. Machira,C.R. Rahmat,I. (2016). Peran dan Motivasi Perawat Kesehatan Jiwa dengan Program Bebas Pasung: Studi Kasus di Mataram. Berita Kedokteran Masyarakat. Vol 32

8. Simamora, R. H. (2019). Menjadi perawat yang: CIH'HUY. Surakarta: Kekata Publisher.

9. Simamora, R. H. (2005). Hubungan Persepsi Perawat Pelaksana Terhadap Penerapan Fungsi Pengorganisasian Yang Dilakukan Oleh Kepala Ruangan Dengan Kinerjanya Diruang Rawat Inap RSUD Koja Jakarta Utara (Doctoral dissertation, Tesis FIK UI, Tidak dipublikasikan).

10. Sukamto,E. Masnina,R. Agustina. (2014). Hubungan Peran Perawat Sebagai Pelaksana Dalam Mencegah Ide Bunuh Diri Pada Penderita Gangguan Jiwa. Jurnal Husada Mahakam. Vol 3

11. Widianti,E. Keliat,B.A. Wardhani,I.Y. (2017). Aplikasi Terapi Spesisialis Keperawatan Jiwa Pada Pasien Skizofrenia dengan Harga Diri Rendah Kronis di RSMM Jawa Barat. Vol 3 
12. Yusuf,Ah. Fitriyasari,R. Nihayati,H.E. Tristiana,Rr.D. (2016). Kompetensi Perawat Dalam Merawat Pasien Gangguan Jiwa. Jurnal Ners. Vol 11 